\title{
The Early to Middle Stone Age Transition and the Emergence of Modern Human Behaviour at site 8-B-11, Sai Island, Sudan
}

\author{
P. Van Peer ${ }^{a *}$, R. Fullagar ${ }^{\text {b }}$, S. Stokes ${ }^{\text {c }}$, R. M. Bailey ${ }^{\text {c }}$, J. Moeyersons ${ }^{\text {d }}$, \\ F. Steenhoudt ${ }^{a}$, A. Geerts ${ }^{a}$, T. Vanderbeken ${ }^{a}$, M. De Dapper ${ }^{\mathrm{e}}$, F. Geus ${ }^{\mathrm{f}}$ \\ ${ }^{a}$ Catholic University of Leuven, Belgium \\ ${ }^{\mathrm{b}}$ University of Sydney, Australia \\ ${ }^{\mathrm{c}}$ Oxford Luminescence Research Group, School of Geography and the Environment, University of Oxford, UK \\ ${ }^{\mathrm{d}}$ Royal Museum for Central Africa, Tervuren, Belgium \\ ${ }^{\mathrm{e}}$ University of Gent, Belgium \\ ${ }^{\mathrm{f}}$ Section Française de la Direction des Antiquités du Soudan - Université Charles de Gaulle-Lille 3, France
}

Keywords: Middle Pleistocene; Sudan; Nile Valley; Early Stone Age; Middle Stone Age; Sangoan; Modern behaviour; Pigments

\section{Introduction}

Site 8-B-11 at Sai Island in northern Sudan is a stratified site containing late Middle and early Upper Pleistocene occupation levels in excellent conditions of preservation. In Middle Pleistocene times, the banks of a small gully were repeatedly occupied by human groups leaving Acheulean and Sangoan material cultures in an interstratified pattern. Optical age determinations on aeolian intercalations within the gully sediments range between 220 and $150 \mathrm{ka}$. This sequence is truncated by Nile floodplain silts in which three occupation levels with Lupemban-related Nubian Complex assemblages (Van Peer, 1998) are stratified. The long archaeological sequence at 8-B-11 is a rare African case to document the Early to

\footnotetext{
* Corresponding author. Philip Van Peer, Laboratorium voor Prehistorie, Redingenstraat 16bis, 3000 Leuven (Belgium).

E-mail address: philip.vanpeer@geo.kuleuven.ac.be (P. Van Peer).
}

Middle Stone Age transition by means of primary context situations in direct stratigraphic superposition (Clark, 2001; Tryon \& McBrearty, 2002). In contrast to the Acheulean, the early MSA Sangoan levels show sophisticated behaviours involving considerable technological and symbolic investment. Quartzite cobbles were used in the grinding of vegetal materials. Yellow and red ochre were exploited and ground to pigments using shaped mortars and selected chert nodules. We conclude that 8 -B-11 is a key site with regard to the initial emergence of modern human behaviour outside subsaharan Africa (McBrearty \& Brooks, 2000).

\section{General description}

Sai (Fig. 1a) is a $50 \mathrm{~km}^{2}$ island located between the second and third Nile cataracts, $10 \mathrm{~km}$ south of the town of Abri (Northern Sudan) whose archaeological importance was recognized in the mid $20^{\text {th }}$ century (Arkell, 1949). It has 

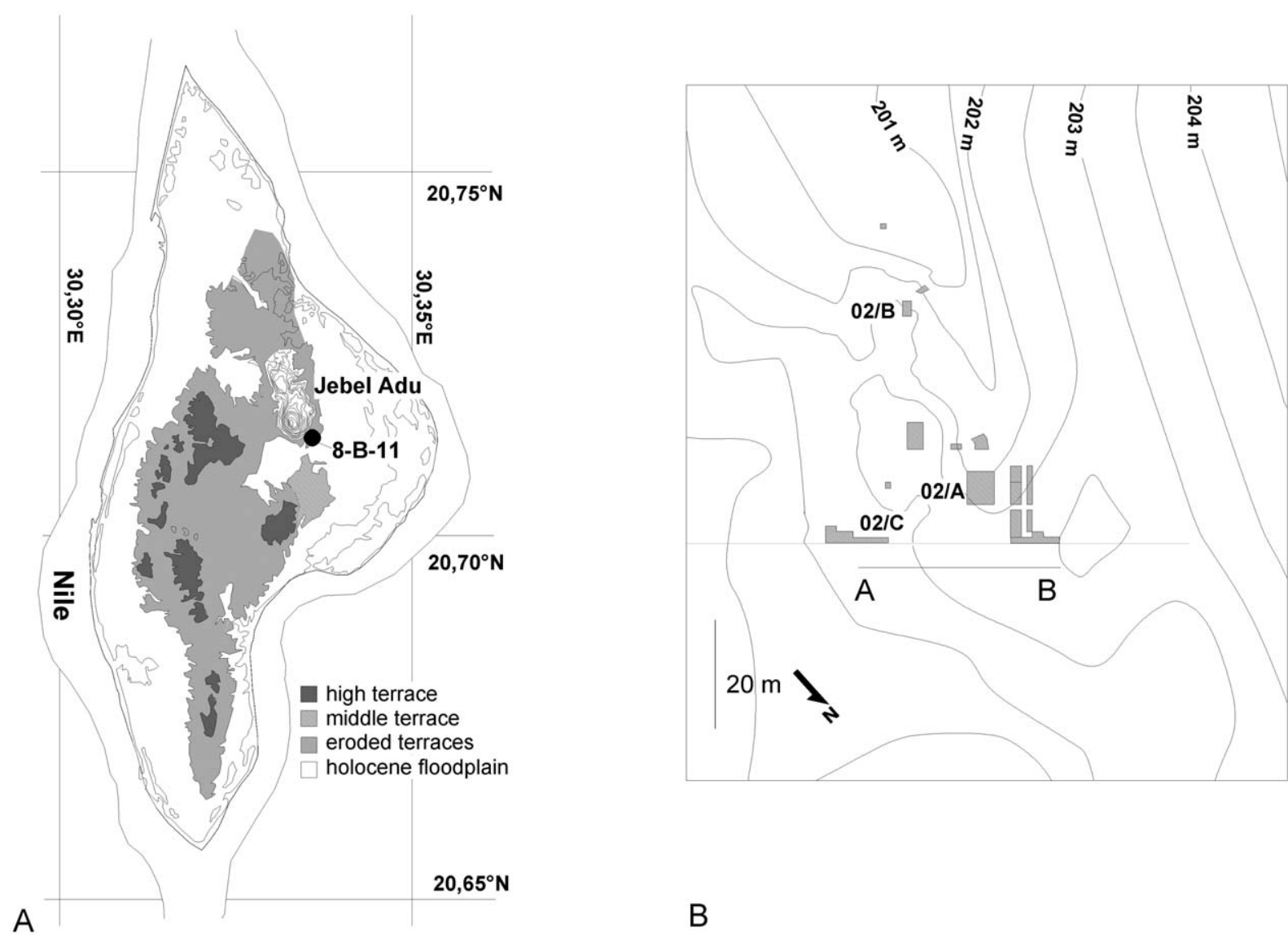

Fig. 1. A: Simplified geomorphological map of Sai Island showing Nile gravel terraces in the centre and a Holocene silt plain at the fringes. 1. B: Topographic map of site 8-B-11 with $0.5 \mathrm{~m}$ contour intervals. Line A-B represents the location of the section presented in Fig. 2. Hatched areas indicate excavation sectors 2000-2002.

been the scene of investigations by a French archaeological mission since the 1950's (Geus, 1995). From 1993 onwards, an interdisciplinary research project was initiated aiming at a complete study of the island's environmental history and human occupation (Geus, 2000).

The geological substrate consists of steeply dipping Precambrian schist with quartz veins, disconformably overlain by subhorizontal Nubian sandstone strata. The latter are mostly only a few meters thick, except for the $75 \mathrm{~m}$ high inselberg of Jebel Adu, in the centre of the island. North of Jebel Adu, sediment cover is limited except at the fringes of the island. Nile gravel terraces are present in the central southern part. A high terrace level at $15 \mathrm{~m}$ above the present floodplain is mainly composed of large quartz cobbles, serving as raw material from Palaeolithic through protohistoric times. The later $10 \mathrm{~m}$ terrace, containing mostly small chert gravels and occasional rolled artefacts, forms the substrate at site 8-B-11, located at the southern foot of Jebel Adu (Fig. 1b).

The $10 \mathrm{~m}$-terrace deposits are incised by a gully, eroding into the Nubian sandstone and filled with a sequence of alternating gravels and sands (Fig. 2). This gully fill is overlain by black Nilotic silts at the deflated top of which a veneer of MSA quartz artefacts, intermingled with river gravels and angular sandstone blocks, occurs. Two in situ occupation levels are stratified within the black 


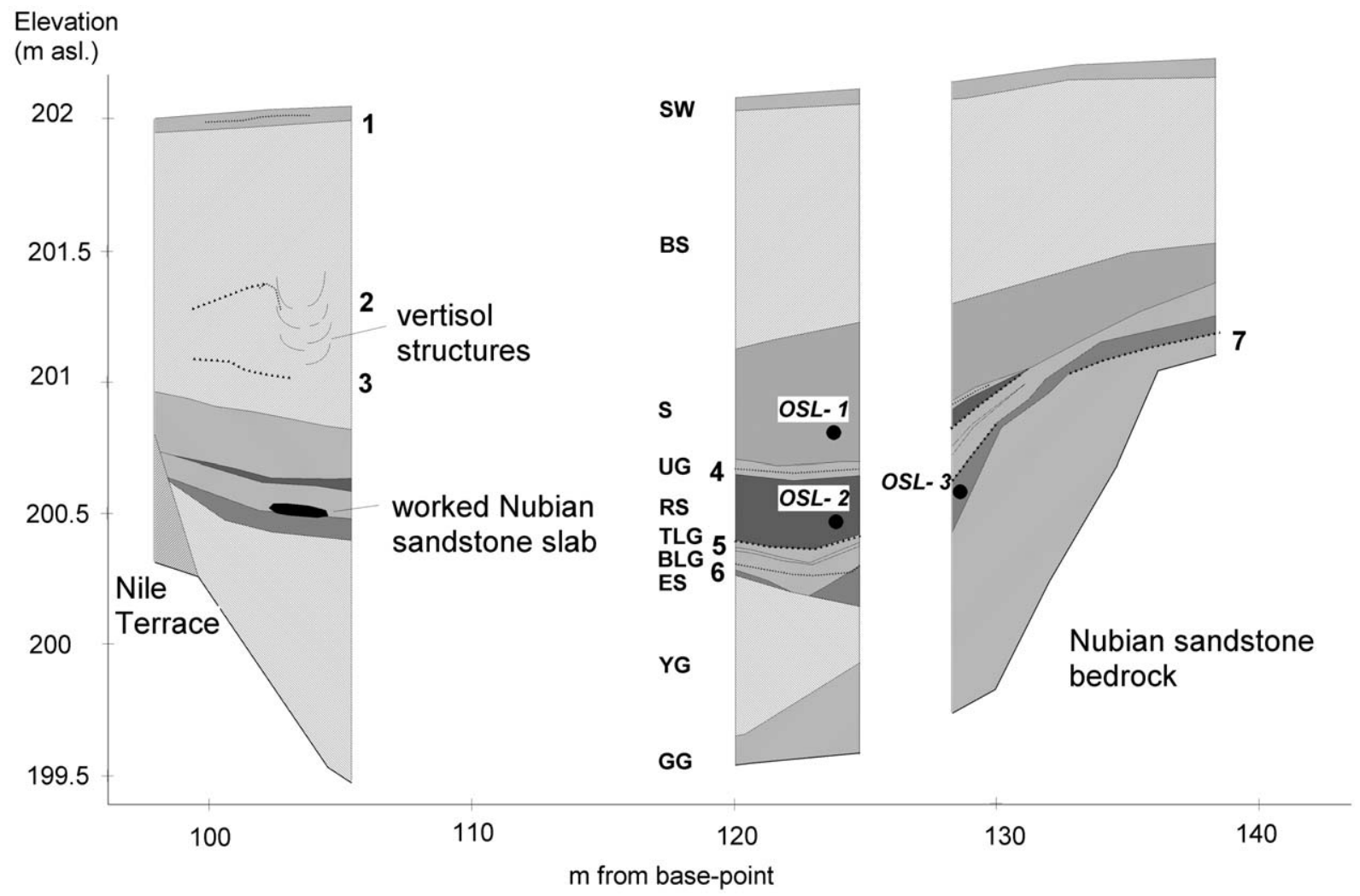

Fig. 2. Synthesis of the stratigraphic succession at 8-B-11. Numbers 1-7 represent the position of archaeological levels (large triangles are primary context situations, small triangles indicate levels affected by a degree of post-depositional reworking): 1-3: Nubian Complex; 4-6: Sangoan; 7: Acheulean.

silts. The lithic assemblages from both the surface and the in situ levels are very similar. Their most prominent typological feature is the presence of thin bifacial foliates. Blanks were produced according to Levallois, Nubian and discoidal reduction strategies (Van Peer, 1992). Technotypologically, the black silt assemblages are similar to those associated with the eastern Saharan OIS 5 paleolakes (Wendorf et al., 1993) and others from the Lower Nile Valley. They all belong to the early Upper Pleistocene Nubian Complex bearing affinities with the sub-Saharan Lupemban (Barham, 2001). In a few places, the black silts show structures like slickensides, dessiccation cracks and bows, organised in plan in polygonal-like configurations. These structures indicate past local vertisol development (Coulombe \& Wilding, 1996; Nyssen et al., 2000).
Several archaeological levels are situated in the gully fill below the black silts, typically at the interface between fine gravel and sandy facies. Human occupations took place on the channel banks, apparently at times when the river regime changed to low-energy, perhaps seasonal, activity. Mostly, the occupation debris occur in primary context and post-depositional disturbance is limited. The artefacts are in fresh condition and there are several refits of pieces found close to each other. Organic remains, however, are virtually lacking and small lithic chips are rare presumably due to slight fluvial sorting.

The lowermost level contains a typologically late Acheulean industry with large lanceolate handaxes in extremely fresh condition. Its spatial distribution is mostly limited to the Jebel Adu pediment slope well above the ancient stream 


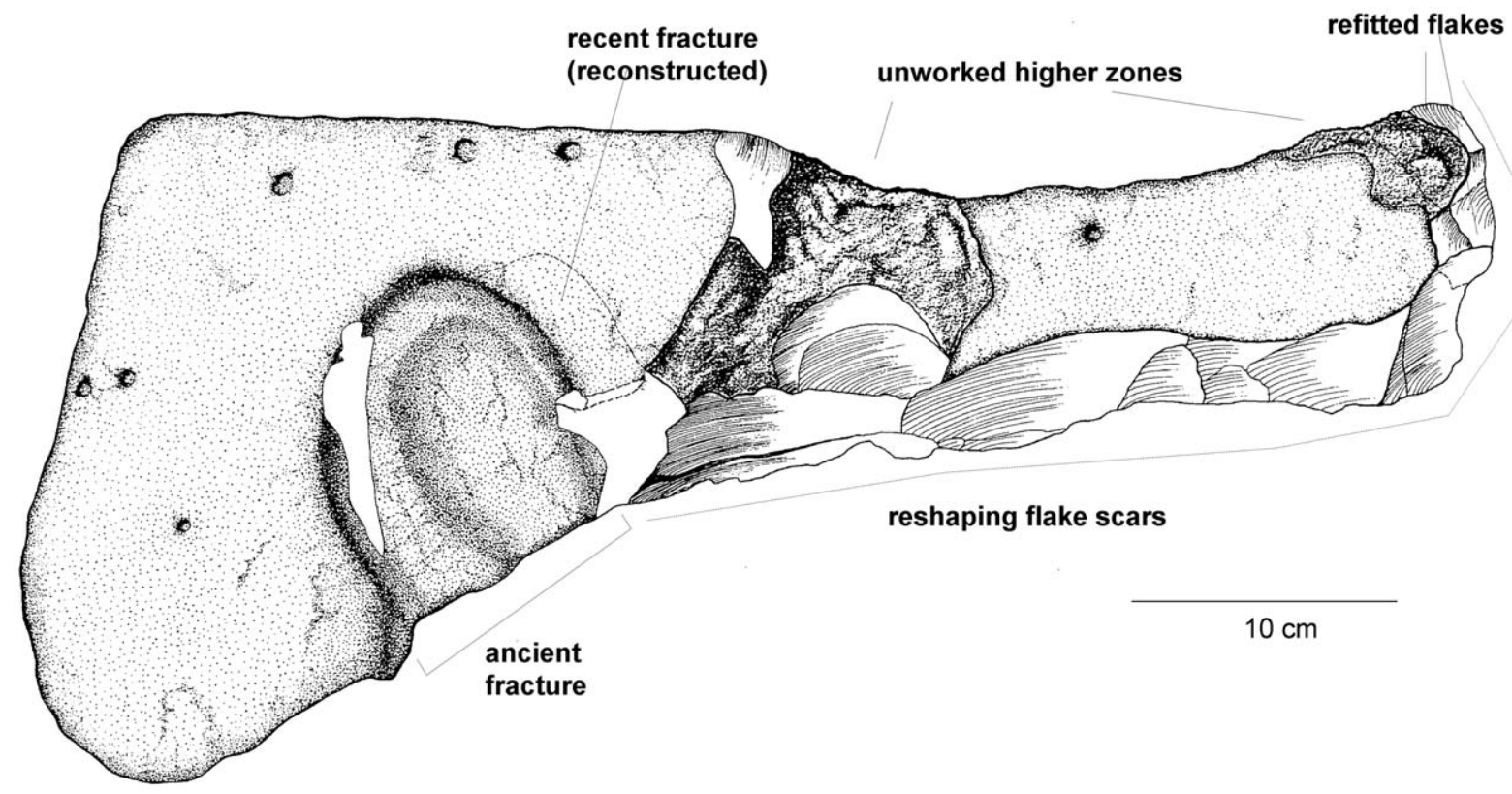

Fig. 3. Worked Nubian sandstone slab found in Lower Sangoan level (level 6 of Fig. 2). White areas represent subrecent fractures.

channel. This may indicate a rather important river activity and a humid climate. An OSLassessment of the overlying aeolian sands (ES) produced quite scattered results but indicates a maximum age of $223 \pm 19 \mathrm{ka}$.

Three occupation levels with lithic assemblages that can be qualified as Sangoan, were found in the gully fill sediments above the ES-sands. Their designation as Lower, Middle, and Upper Sangoan only refers to their relative chronological position at this site. The Lower Sangoan occurs in a fine gravel deposit (BLG) attesting to a new fluvial phase. This BLG-gravel has eroded archaeological material from the top of the ESsands. In some areas upslope, however, these artefacts are still in their original stratigraphic context. Handaxes are not present in this assemblage. Blanks are produced from discoidal and globular cores, but flake tools are very rare. Heavy-duty equipment is well represented, including hammerstones, grinding stones, and several core-axes (Clark \& Kleindienst, 2001). In this Lower Sangoan level, we observed the presence of a dense concentration of red and yellow ochre lumps, some with ground surfaces. An extraordinary object (Fig. 3) was found in trench $02 / C$, near the southern edge of the Middle Pleistocene gully (Fig. 2). The overall shape of this $10 \mathrm{~cm}$ thick Nubian sandstone slab is the result of human action. Steep flake negatives are present on its sides, except for the lower right part of the perimeter where oblique flake scars occur. Two of these flakes were found near the slab and refitted onto its right side. Apparently, these scars represent posterior reworking.

Except for small areas in the centre and to the right, the upper face of the slab is made perfectly flat by pecking. A large depression, of which the sides have suffered both ancient and recent fracture, was cut out and seems to be surrounded by a series of small pits. This object may have served as a grinding stone or mortar. Several small chert pebbles with particles of yellow/red ochre adhering to one of their faces are present in this level. They are similar in size and appearance, displaying a brown/red colour with black inclusions. One of them shows a thick wear polish. Another one has streaks of red and yellow pigment applied on one of its faces. As chert pebbles of this appearance are rare in the natural gravels of the gully fill sequence, 


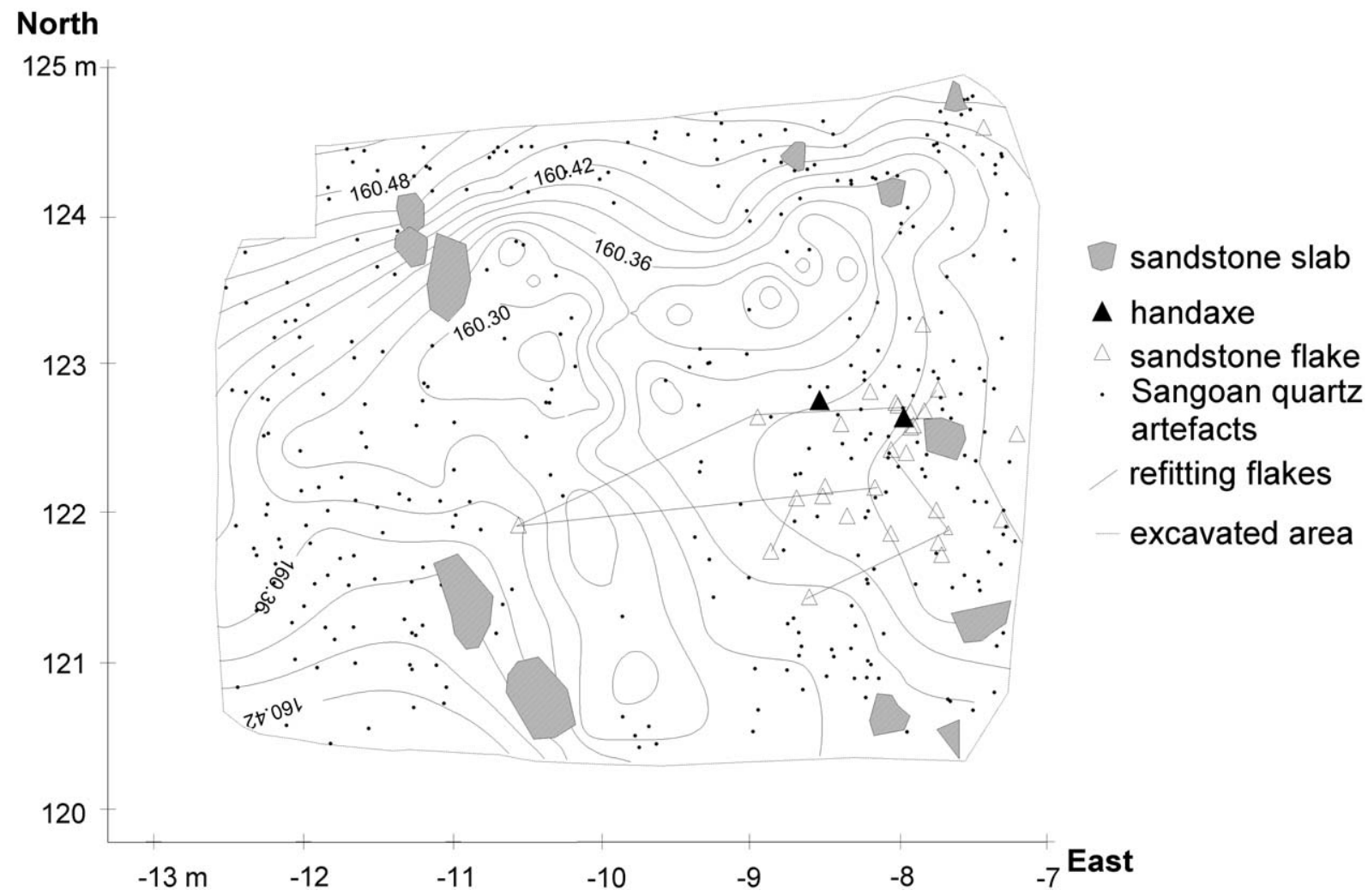

Fig. 4. The distribution of artefacts in the Middle Sangoan level in excavation sector 02/A (level 5 of Fig. 2). The topography of the top of the underlying sediment is shown by contour lines at $2 \mathrm{~cm}$ intervals.

we assume that they were deliberately selected. This may suggest that their use as pigment grinders was surrounded with a degree of symbolic connotation.

The Middle Sangoan occupation level rests on top of the TLG-gravel separated from BLG by a thin layer of coarse sand. An intricate horizontal network of large calcified roots is present here, remnants of an extensive vegetation cover in the ancient black silt floodplain. Artefacts are packed in a thin lens of clay. Quartz core-axes of Khor Abu Anga type are present (Guichard \& Guichard, 1965). Two slabs, forming part of a more or less circular arrangement with a radius of $2.5 \mathrm{~m}$ (Fig. 4), show similar cut-out depressions as the one found in the Lower Sangoan. Possibly they are mortars that were re-used as structural elements. Furthermore, a number of imported quartzite cobbles with wear facets are present. Two of them were studied microscopically and a soft white coating was analysed using X-ray diffraction. Three major components were identified: major quartz and calcite with minor feldspar (R. Pogson, personal communication). Areas of polish on both artefacts were also analysed, and aqueous solutions were removed in a sonic bath for transmitted light microscopy. Phytoliths and starch granules were recovered. Their presence in association with very bright flat polished surfaces supports the hypothesis that the cobbles were used to process siliceous and starchy plant tissues, possibly grass seeds. Identification studies are currently underway.

In the eastern part of trench 02/A, a discrete concentration with two lanceolate handaxes and sandstone flakes belonging to one handaxe production sequence, occurs among the scatter of Middle Sangoan quartz artefacts (Fig. 4). This is 
the only instance where the presence of handaxes is attested in any of the Sangoan levels. One handaxe is out of chert and the other out of ferrocrete sandstone, raw materials that are practically absent in the Sangoan. Furthermore, a complete lithic reduction sequence as found here has never been met in the Sangoan. We infer that the archaeological debris found at this land surface are the result of two separate events of human activity, one leaving a Sangoan assemblage and the other an Acheulean. The profound differences in terms of typology, raw material use, and site use suggest that this palimpsest situation represents the occupation of the site by two different behavioural systems.

The final infilling of the gully is represented by a $0.5 \mathrm{~m}$ thick unit of sands with intercalated gravel lenses. A sand sample from the base of this unit, right above the Middle Sangoan produced an optical age of $182 \pm 20 \mathrm{ka}$. Another one taken at the top, above a gravel lens (UG) in which the Upper Sangoan occurs in secondary context, is optically-dated to $152 \pm 10 \mathrm{ka}$. The gully sequence is finally capped by the black silt floodplain.

\section{Conclusions}

Site 8-B-11, the first in the northern Nile Valley to present an archaeological sequence spanning the late Middle and the early Upper Pleistocene, leads to several conclusions. Together with Kalambo Falls (Clark, 2001; McBrearty, 2001), it strengthens the case for identifying the long-debated Sangoan as a valid taxonomic entity for the early Middle Stone Age, with a geographical distribution extending far beyond the Congo basin (Cahen, 1976; McBrearty, 1987). Earlier suggestions of a Sangoan presence in the Lower and Middle Nile are now confirmed (Arkell, 1949; Chmielewski, 1968). It is of particular interest to note that in the small lithic assemblage from Abu Hagar (Lacaille, 1951), found close to the Homo helmei cranium from Singa (Stringer et al., 1985; McBrearty \& Brooks, 2000) and likely from the same stratigraphic position, the same lithic types as in the Sai Sangoan are present.

Second, the Early to Middle Stone Age transition at this site shows itself as an interstratification between Acheulean and Sangoan assemblages. These two material cultures were produced contemporaneously by groups who occupied the same land surfaces in the period around $200 \mathrm{ka}$ ago. In East Africa, the ESA/MSA transition is now placed before $285 \mathrm{ka}$ ago (Tryon \& McBrearty, 2002). Such evidence may suggest that the appearance of the Middle Stone Age in northern Africa is a consequence of population replacement.

Third, recent evidence for the high antiquity of modern behavioural features in Africa (McBrearty \& Brooks, 2000; Barham, 2001) is amplified. At site 8-B-11, complex processing of plant foods and symbolic pigment treatment are attested from the earliest Sangoan occurrences onwards. In the transition to the Middle Stone Age, modern behaviour can be seen to emerge and the geographical distribution of the Sangoan may be the reflection of its early dispersal in large parts of Africa.

\section{Acknowledgements}

The interdisciplinary project at Sai Island is co-sponsored by the French Ministry of Foreign Affairs and the Research Council of the Katholieke Universiteit Leuven, Belgium (grant OT/01/10). We thank Francesco D'Errico for preliminary comments on the object in Fig. 3. We thank the National Corporation for Antiquities and Museums of Sudan and its inspectors in the field for good collaboration. The drawing shown in Fig. 3 is by Sigrid Missotten. Optical dating was supported by a grant from the UK NERC under the EFCHED.

\section{References}

Arkell, A.J., (1949). The Old Stone Age in the Anglo-Egyptian Sudan. Sudan Antiquities Service Occasional Papers, 1, Khartoum.

Barham, L., 2001. Central Africa and the emergence of regional identity in the Middle Pleistocene. In: Barham, L., Robson-Brown, K. (Eds.), Human Roots. Africa and Asia in the Middle Pleistocene. Western Academic \& Specialist Press, Bristol, pp. 81-98.

Cahen, D., 1976. Nouvelles fouilles à la pointe de la Gombe (expointe de Kalina); Kinshasha, Zaire. L'Anthropologie $80,573-602$. 
Chmielewski, W., 1968. Early and Middle Paleolithic sites near Arkin, Sudan. In: Wendorf, F. (Ed.), The Prehistory of Nubia. Fort Burgwin Research Center and Southern Methodist University Press, Dallas, pp. 110-147.

Clark, J.D., 2001, Kalambo Falls Prehistoric Site. Volume III. Cambridge University Press, Cambridge.

Clark, J.D., Kleindienst, M., 2001. The Stone Age cultural sequence: terminology, typology and raw material. In: Clark, J.D. (Ed.), Kalambo Falls Prehistoric Site. Volume III. Cambridge University Press, Cambridge, pp. 34-65.

Coulombe, C., Wilding, L.P., 1996. Overview of Vertisols: characteristics and impacts on society. Advances in Agronomy 57, 289-375.

Geus, F., 1995. Archaeology and History of Sai Island. The Sudan Archaeological Research Society Newsletter 8, 27-34.

Geus, F., 2000. Geomorphology and prehistory of Sai Island (Nubia): report on a current research project. In: Krzyzaniak, L., Kroeper, K., Kobusiewicz, M. (Eds.), Recent Research into the Stone Age of Northeastern Africa. Studies in African Archaeology 7. Poznan Archaeological Museum, Poznan, pp. 119-128.

Guichard, J., Guichard, G., 1965. The Early and Middle Paleolithic of Nubia. In: Wendorf, F. (Ed.), Contributions to the Prehistory of Nubia. Fort Burgwin Research Center and Southern Methodist University Press, Dallas, pp. 57-116.

Lacaille, A.D., 1951. The Stone industry of Singa-Abu Hugar. Fossil Mammals of Africa, No2, The Pleistocene Fauna of two Blue Nile Sites. British Museum, London, pp. 43-51.
McBrearty, S., 1987. Une évaluation du Sangoen: son âge, son environnement et son rapport avec l'origine de l'Homo sapiens. L'Anthropologie 91, 487-510.

McBrearty, S., 2001. The Middle Pleistocene of East Africa. In: Barham, L., Robson-Brown, K. (Eds.), Human Roots. Africa and Asia in the Middle Pleistocene. Western Academic and Specialist Press, Bristol, pp. 81-98.

McBrearty, S., Brooks, A.S., 2000. The Revolution that wasn't: a new interpretation of the origin of modern human behaviour. J. Hum Evol. 39, 453-563.

Nyssen, J., Moeyersons, J., Deckers, J., Mitiku, H., Poesen, J., 2000. Vertic movements and the development of stone covers and gullies, Tigray Highlands, Ethiopia. Z. Geomorph. N.F. 44, 145-164.

Stringer, C.B., Cornish, L., Stuart-Macadem, P., 1985. Preparation and further study of the Singa skull from Sudan. Bulletin of the British Museum of Natural History (Geology) 38, 347-358.

Tryon, C.A., McBrearty, S., 2002. Tephrostratigraphy and the Acheulian to Middle Stone Age transition in the Kapthurin Formation, Kenya. J. Hum Evol. 42, 211-235.

Van Peer, P., 1992. The Levallois Reduction Strategy, Monographs in World Archaeology 13. Prehistory Press, Madison.

Van Peer, P., 1998. The River Nile Corridor and Out of Africa: an Examination of the Archaeological Record. Curr. Anthrop. 39, S115-S140.

Wendorf, F., Schild, R., Close, A.E., Associates, 1993. Egypt during the Last Interglacial: the Middle Paleolithic of Bir Tarfawi and Bir Sahara East. Plenum Press, New York. 